\title{
DAILY PRACTICES AND PROCESSES OF TERRITORIALIZATION OF SETTLERS IN QUERÊNCIA DO NORTE, PARANÁ, BRAZIL ${ }^{1}$
}

\author{
ELINE G. O. ZIOLI 2,3 $^{2,3}$ \\ (iD) https://orcid.org/0000-0001-6771-6714 \\ FÁBIO S. RODRIGUES ${ }^{4}$ \\ (iD) http://orcid.org/0000-0002-3395-5124 \\ EVANDRO L. GAFFURI ${ }^{3}$ \\ (D) https://orcid.org/0000-0002-2716-1504 \\ ELISA Y. ICHIKAWA ${ }^{3}$ \\ (iD) https://orcid.org/0000-0001-7096-7653
}

To cite this paper: Zioli, E. G. O., Rodrigues, F. S., Gaffuri, E. L., \& Ichikawa, E. Y. (2021). Daily practices and processes of territorialization of settlers in Querência do Norte, Paraná, Brazil. Revista de Administração Mackenzie, 22 (2), 1-28. doi:10.1590/1678-6971/eRAMG210133

Submission: July 1, 2019. Acceptance: June 17, 2020.

\footnotetext{
We would like to thank CNPq (National Board of Scientific and Technological Development) for financial support in the conducting of this study.

2 Federal Institute of Education, Science and Technology of São Paulo (IFSP), Boituva, SP, Brazil.

3 State University of Maringá (UEM), Maringá, PR, Brazil.

4 Federal University of Mato Grosso do Sul (UFMS), Naviraí, MS, Brazil.
}

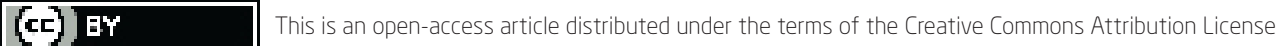

\footnotetext{
This paper may be copied, distributed, displayed, transmitted or adapted for any purpose, even commercially, if provided, in a clear and explicit way, the name of the journal, the edition, the year and the pages on which the paper was originally published, but not suggesting that RAM endorses paper reuse. This licensing term should be made explicit in cases of reuse or distribution to third parties.

Este artigo pode ser copiado, distribuído, exibido, transmitido ou adaptado para qualquer fim, mesmo que comercial, desde que citados, de forma clara e explícita, o nome da revista, a edição, o ano e as páginas nas quais o artigo foi publicado originalmente, mas sem sugerir que a RAM endosse a reutilização do artigo. Esse termo de licenciamento deve ser explicitado para os casos de reutilização ou distribuição para terceiros.
} 


\section{ABSTRACT}

Purpose: To understand the processes of territorialization in the daily life and work routine of settlers in Querência do Norte, Paraná, Brazil. Originality/value: This work contributes to the context of discussions on territory and territorialization processes (Haesbaert, 2011; Raffestin, 1993, 2008; Saquet, 2008) in the daily life (De Certeau, 2014) of workers marginalized by society in general.

Design/methodology/approach: We developed this qualitative article from data collected through eight life history interviews with settlers, pre-settlers, and residents of Querência do Norte, in the State of Paraná (PR). After transcribing the interviews, they went through an analysis of narratives.

Findings: We identify that, through the practices of work, study and claims, the settlers territorialize the space, and there they create their own rules and norms of coexistence. In their struggles for land, it is clear that their place of belonging is the field, justifying the insistence on the struggle for the right to land to cultivate. The sense of belonging of the workers is represented by the struggle that unites them and places them as part of a larger movement. Placing men at the center of the construction of territoriality is accomplished through the daily struggle and work of the settlers and pre-settlers in Querência do Norte (PR).

\section{KEYWORDS}

Everyday life. Territory. Processes of territorialization. Settlers. Querência do Norte (PR). 


\section{INITIAL CONSIDERATIONS}

According to Reis (2012), the distribution of land in Brazil is an issue permeated by popular conflicts and revolts, including Canudos, Contestado, the War of Formoso, the Farmer Leagues, and the MST (Landless Rural Workers' Movement). The relevance of social movements resides in their capacity to influence the discourses, procedures, and behavior of the State (Hollender, 2016). As Fernandes (2017) points out, the actions of social movements are a way of resisting the neglect of the State.

As Meszaros (2000) emphasizes, in Brazil, the fight for land has been a continual characteristic of the nation's history. The MST, one of the most important social movements in Brazil, was born from the determination to fight against new forms of aggression against the poorest section of society, mainly farmers ${ }^{5}$ and it has challenged the distribution of land, as well as the logic of the Brazilian capitalist development (Meszaros, 2000). The group was formally organized in 1984 (Straubhaar, 2015) and has been one of the most important and long-lasting movements for agrarian reform in the history of the world and the main one in Latin America (Carter, 2009). However, the actions of the MST and the representativeness of social movements are still marginalized within the context of administration studies.

But why should we reflect on the subject of territorialization based on the everyday lives of these people? How will this discussion contribute to organizational studies? What are the possible connections between this subject and the object of proposed studies and Administration? Among the possibilities which can be addressed to justify these connections, there are some which deserve more attention. The first argument refers to the omission - or perhaps intentional forgetting - of controversial subjects, such as the issue of land disputes and territorialization processes by administration journals. As Barros and Carrieri (2015) argue, the hegemonic perspective is predominant in organizational studies, resulting in the marginalization of objects and theories outside this dominant context.

For decades, the dominant subjects of journals in this area have addressed - and still address - subjects that interest the mainstream, based on the perspective of the powerful ones in society. This reality, observed

The term "peasant", used by Meszaros (2000), refers to the historical-political content of the term, which according to Wanderley (2014), denotes the entire history of battles by the Brazilian peasantry; however, for the development of this study, we will use the term family farmers, which as Wanderley (2019) points out, can be used as an equivalent to the term peasant. 
within organizations, is also manifested in the research field of Administration. The Anglo-Saxon domination of the field of Administration reflects the colonization process of knowledge and learning in organizational studies (Alcadipani, Khan, Gantman, \& Nkomo, 2012; Ibarra-Colado, 2006). The diversity observed in the daily operations of organizations reveals a universe that is little known and has been little explored. This diversity can be studied based on the everyday experiences of people, and the strategies and survival tactics adopted by these autonomous subjects, and the normal management practiced by them (Barros \& Carrieri, 2015).

In this sense, the challenge that this research problem and the adopted theoretical references present is to reflect or perhaps understand the nuances of these subjects, which do not occupy leadership or strategic positions in large organizations. As Carrieri, Perdigão, and Aguiar (2014) argue, managerialism has dominated the process of constructing Administration, legitimizing it as a reference or a standard within the management model based on rigid and formal models of management. The challenge of this study is to reveal these invisible subjects, based on the perspective of De Certeau (2014), externalizing their voices and experiences, allowing them to reverberate in a field historically dominated by powerful subjects, following the historic suffocation, repression, and neglect of the voices of the humble, ordinary and common people.

Another aspect that legitimizes the discussion of land and everyday Administration is based on the position that administrative studies do not refer just to profit-oriented businesses but also to other types of organizations, such as social movements, which present the reality of other forms of management. Thus, we emphasize the ordinary management proposed by Carrieri et al. (2014, p. 698), which "avoids managerialist parameters", because it focuses on the everyday experiences of these ordinary people, which we will present through this study.

Methodologically, the theoretical-empirical reflection realized in this article makes it possible to transpose theories and theoretical assumptions from other areas of knowledge to organizational studies. Since its origins, Administration has been constructed based on contributions from other areas of knowledge (Rodrigues, 2019). As Barros and Carrieri (2015) argue, the dialogical use of theories from other areas of knowledge makes it possible for new knowledge to appear in the area of Administration. This contributes by making connections with current history in order to understand facts in their subtleties and details, which other methods of data collection, such as those based on instrumental logic, may not support. 
This study also constitutes possibilities for public administration and actions of the State by presenting the reality of the life and work of those who work in settlements and pre-settlements of the agrarian reform, whose needs do not end with the constitution of a settlement. Unseen and unheard, these people, who make up the mass of rural settlers, campers, or those in the process of settling, are invisible when they are not summarily ignored in the process of planning public policy.

The justification of the relevance of examining the MST in an administration study is also due to the changes that the movement has succeeded in winning for the reality of Brazilian rural workers. The state of Paraná, which is essentially agricultural and is where the MST was born, naturally is not exempt from most of its demands. Querência do Norte, a municipality situated in the extreme Northeast of the State, is an example of how these state battles occur. Godoy and Silva (2008) emphasize the influence of the MST in the growth of the consumer market, underlining the changes that have occurred in the municipality. The municipality of Querência do Norte has 785 families in 10 settlements (National Institute of Colonization and Agrarian Reform - Incra, 2017). Since the arrival of the MST, there has been an increase in the level of economic activity in the municipality, as well as more dynamic commerce, given that the region's large landowners did not exploit their land and lived outside the municipality (Godoy \& Silva, 2008). However, the battles for land in the municipality predate the arrival of the MST and date from the construction of the municipality, in 1950, and the arrival of rural workers and squatters (Gonçalves, 2004).

It was a scenario of uncertainties and difficulties for family farmers, their business partners, tenants, and those who occupied the municipality's land, with no guarantees in terms of working conditions and in the chance to own land, while the government's actions benefitted the municipality's large property owners. It was in 1985 that the municipality's Rural Workers' Union began to focus on agrarian problems, with the objective of realizing settlements in Querência. Thus, in 1988, the 29 Pontal do Tigre farm was singled out as a priority area for disappropriation and agrarian reform, and it was subsequently occupied by 200 families from other MST camps (Gonçalves, 2004).

The MST's fight for land is the fight for territory in the sense of a physical space to settle its workers. However, for the purposes of this study, it is understood that, in addition to the physical sense of these spaces, the territory is the result of an actor's action "to appropriate a space concretely or abstractly" (Raffestin, 1993, p. 143). Therefore, besides representing a geo- 
graphically delimited space, the territory also characterizes the subject's space of action, territorializing not just in a legal and concrete form in defining the legitimate owner of space but also promoting the appropriation of space in an abstract form. Based on the subject's everyday experiences, we seek to observe the process of territorialization which accompanies the movement for space (De Certeau, 2014).

Within this context, the objective of this article is to understand the processes of territorialization in everyday life and work of the agrarian reform settlers in the municipality of Querência do Norte (PR). In this way, we can broaden the perspective of Administration in terms of the issue of work, disassociating it from the traditional perspective, which emphasizes the practices of formal organizations and expresses it through the voices of workers who construct in their new environment new movements of space. We have developed this study based on the life stories of settlers of Pontal do Tigre, Sebastião da Maia, and Margarida Alves, as well as the residents of the pre-settlement of Água do Bugre farm and city residents who work directly with family farmers in the settlements.

This article is divided into six parts: after the initial considerations, we have the theoretical presentation of Michel de Certeau's work in terms of everyday experiences. The third part introduces theoretical discussions related to territory and territorialization, while the fourth presents the methodological procedures used in this study. Then we analyze life stories and their relationship with the theoretical aspects supported by this work, and, finally, we present our final considerations.

\section{EVERYDAY EXPERIENCE ACCORDING TO DE CERTEAU}

Interest in the everyday lives of common people and everyday practices have intensified recently in the field of Brazilian organizational studies. In this aspect, questioning typical hegemonic mainstream learning and thinking of new research possibilities based on the use of history, giving visibility to the stories of common people, ordinary businessmen, and common workers as Barros and Carrieri (2015) do, have become renewed possibilities. As Ribeiro, Ipiranga, Oliveira, and Dias (2019, p. 591) argue, this interest carries with it "[...] the social and political sense of practices which are expressed subjectively in a patchwork which is full of contradictions", constructed based on everyday movements, derived, in turn, by activities exercised by social actors which unfold in events which provoke changes in the course of events. 
The following recent studies in the field of organizational studies are worthy of notice: Carrieri, Saraiva, and Pimentel (2008) study hippy fairs in Minas Gerais, focusing on subversive actions of survival in the face of the process of institutionalization; Oliveira and Cavedon (2013) analyze everyday life in a circus based on ethnography; Teixeira, Saraiva, and Carrieri (2015) conduct a discussion of identity and the everyday life of maids; Ribeiro et al. (2019) articulate a discussion based on the feminist perspective and the practice of artisan resistance, discussing the issues of ordinary women; and Domingues, Fantinel, and Figueiredo (2019) use ethnography to examine the organizational space of an artisan fair in the State of Espírito Santo from the points of view of Henri Lefebvre and Michel de Certeau.

Within this context, one of the main everyday references comes from Michel de Certeau, whose works portray, as Kuus (2018) indicates, the contingent and situational nature of social practices. Studying everyday life, according to Courpasson (2017), is characterized by an attention to the casual and the possibility of emancipating the dominant rhythms, restrictions, and fatalities, which rest in the common gestures of everyday life. This extraordinary dimension of ordinary routines (Machado da Silva \& Leite, 2008) becomes obvious in the experience of urban occupations, in battles for housing, subject to conflicts and disputes for territory (Santos, 2019), in which ordinary subjects adjust their common needs to emerging exceptions. However, the ordinary perspective of everyday life is essential to continue in exceptional situations (Machado da Silva \& Leite, 2008). Repression, violence, and other coercive forms of intimidating ordinary subjects in their fight for land in the country, as well as in the city, represent these exceptions, which change the natural everyday rhythm of the common individual's everyday life, requiring them to give up these social practices.

De Certeau focuses on the individual (Best \& Hindmarsch, 2018), the common man, who apparently gives in to passivity and is treated as a secondclass citizen, and is generally conceived of as an individual subject in social life (De Certeau, 2014). Looking at the actions of ordinary men in everyday life unveils the strategies of the powerful, who define the rules of the game of everyday life, as well as the possibilities that an ordinary man has in terms of action within this context (De Certeau, 2014; Courpasson, 2017). Within these possibilities of action, the astute ability of the ordinary subject to adjust to opportunities that arise in everyday life, reconciling the ordinary and the extraordinary, can be visualized in urban occupations (Santos, 2019).

De Certeau (2014) emphasizes that a relationship exists - which is always social - which sets relational determinations in which each individual 
is the locus where a given inconsistent plurality acts, sometimes in a contradictory manner. Thus, more than analyzing the subject itself, the interest in everyday practices is focused on modus operandi, which refers to the everyday art practiced by these subjects. In making use of some social practices, the ordinary men carry with them millennial codes culturally imprinted in them, which are obscured in these subjects, hidden by a mask of rationality typical of the West. In the sense proposed by De Certeau, exhuming refers to revealing these subliminal codes built into the actions of these people, whom the author calls consumers.

Treating these subjects as consumers reveals the silent and subversive production, which Ortmann and Sydow (2017) refer to as almost invisible, representing new ways of using the rules, routines, and resources available to these subjects. Within this scenario, the game of everyday life occurs on a field of tension and conflict, in which the subjects play employing different forces, which can be understood based on the concepts of strategy and tactics. A strategy is the calculation of force relationships of a powerful individual, an owner who uses them to define the rules of the political, economic, or scientific game. Tactics, in turn, are the expedients employed by the ordinary man since he is not an owner and operates blow-by-blow in another's space in an astute, stealthy, and incremental manner. If, on the one hand, the strategy is a victory of the place over time, considering that this individual has no place, tactics are, on the other hand, the victory of time over place, of the individual over himself (De Certeau, 2014; Munro, 2017; Frers \& Meier, 2017; Nielsen \& Langstrup, 2018; Gangneux \& Docherty, 2018).

The ordinary man sustains himself within the gaps left by society, using them as opportunities to be taken advantage of when it is convenient (De Certeau, 2014; Ortmann \& Sydow, 2017). It is the "art of getting around things" (Telles, 2010, p. 25), which astute individuals use to adjust to everyday situations. In a stealthy way, they seek to take advantage of situations to create occasions like artists and artisans, who should be in places where no one expects them, being astute (Ribeiro et al., 2019). Tactics are ways to reveal the possibility of victories of the weak over the strong, who express themselves incrementally to take advantage of apparently adverse situations (Redshaw, 2017; Duarte \& Brewer, 2019). If the direct confrontation with the powerful does not always seem to be the best alternative, it is not rejected directly, given the use of their abilities in social metamorphosis and in reinventing their possibilities in terms of artifacts as well as spaces as an alternative to well-trodden everyday paths (De Certeau, 2014). This astute tactical practice has to do with what De Certeau (2014) calls metis, a term originated by the Greeks which refers to this type of astute intelligence. 
It is in everyday experience that the tension exists between owners who define strategies and the ordinary men who only possess astute practices. The trajectory of resistance of an artisan (Ribeiro et al., 2019) reflects this practice of using these tactics and crafts as a way to maintain his or her existence in the face of the mechanisms of oppression. Seeking shelter, as demonstrated in the study of Santos (2019), is a field of battles and disputes in the urban arena, in which the stealthy practices of ordinary people combine with the need to combine the ordinary and extraordinary in order to survive.

It is within this context of possibilities that De Certeau (2014) makes an important discussion regarding place and space. The author calls "place" the order of distribution of the elements in the relationship of coexistence, in which, analogous to the laws of physics, two bodies cannot occupy the same space. In this sense, the physical logic prevails, given that the frontiers and order of spaces are defined as the limits of each subject, indicating stability, a configuration of positions at a certain instant. Based on this logic, a place appears to be static. Space, in turn, has to do with dynamism, which consumes the intersection of possibilities admitted by the variables of time, velocity, and direction. Space, from this perspective, is movement, since it is, to De Certeau (2014), a practiced place. In the following section, we will discuss how space may be territorialized.

\section{TERRITORY AND TERRITORIALIZATION}

The concepts of territory can be placed into three basic groups: political, which deals with relationships of space and power; cultural, in which territory is the product of the symbolic appropriation or valorization of a group in relation to a living space; and economical, which focuses on the spatial dimension of economic relationships, in which territory is a source of resources (Haesbaert, 2011). Folmer and Meurer (2019) emphasize that the concept of territory is a way to designate spaces constructed based on social practice (relationships) that subjects establish and their dynamics. To understand the concept of territory, it is important to analyze its relationship with the concept of space, given that they cannot be considered equivalents or synonyms (Raffestin, 2008; Folmer \& Meurer, 2019).

In terms of the difference between territory and space, Picheth and Chagas (2018, p. 790) point out that "territory rests on space, but is a production that occurs through it". The territory is constructed by the subject, while space precedes territory, which is generated based on space, through the 
actions of the subject, bringing into focus studies of territory through the actions of the subject and fleeing the understanding of the territory as material beyond the subject's actions (Raffestin, 2008).

The construction of a territory by a subject occurs, as Raffestin (2008) points out, through the concrete or abstract appropriation of space, and in this way, the subject territorializes his or her space. Therefore, in the view of this author, territorialization can be understood as the creation of territories through a direct or indirect, objective or subjective appropriation by the subject. The concept of territoriality refers to "the multidimensionality of territorial 'living' experienced by members of a collective, and by societies in general”, as pointed out by Raffestin (1993, p. 158). It is in this sense that Koch (2017) presents Raffestin's territoriality as a practice between actors and as essentially relational. Thus, territoriality is a form of relational behavior in which the nature of relationships is more important than the physical space in which they occur (Sewell \& Taskin, 2015).

Defined as a group of relationships, territoriality originates in the tridimensional system of society-space-time (S-S-T), which refers to the relationship between society, space, and time in the construction of territorialities (Raffestin, 1993). Life is made up of relationships, and, for this reason, Raffestin (1993) defines territoriality as a group of relationships that involve a subject who belongs to a collective, a relationship that possesses form or content. Exteriority or a place is an abstract space, an institutional, political, or cultural system. Time in Raffestin's (1993) tridimensional system represents variations which the elements society and space exhibit, being susceptible to variations over time.

Therefore, territoriality refers to social relationships "which historically produce each territory" (Saquet, 2008, p. 79), being, in this sense, production based on space (Saraiva, Carrieri, \& Soares, 2014). As Fuini (2019) points out, territoriality is linked to the idea of a group's belonging to a territory. As presented by Saquet (2008), territorialization is constituted by various temporalities and multidimensional territorialities. "Territorialization is the result and condition of social and spatial processes and signifies historical and relational movement" (Saquet, 2008, p. 83). Raffestin (1993, p. 161) stresses that territoriality is made up of "mediated relationships, which are symmetric or asymmetric with exteriority", therefore talking of territoriality is talking about production, exchange, and consumption, and not a simple link to space.

The relational nature of territory is also addressed by Haesbaert (2011, p. 82), who deals with its definition "within a group of historical-social rela- 
tionships" as well as the complex relationship between social processes and material space. Based on this understanding, we can understand territory as movement, fluidity, interconnection, or, in other words, temporality. The territorial production described by Raffestin $(1993,2008)$ is a process of territorialization or the construction and appropriation of territory, which generates, as Saquet (2008, p. 88) points out, identities and heterogeneities, which in turn, generate territories.

Territorialization involves an actor (individual or collective), work, the disposition of the actor (a combination of energy and information), and material mediators (instruments, materials, knowledge). Raffestin (1993, 2008) emphasizes the following components in the process of territorialization: the realizable intentions of the actor's objectives, the relationship between the actor and the general environment, the organic and inorganic environments, the social environment, the general environment (organic, inorganic and social environments), the territory produced by the actor in the environment, and the group of relationships developed by the actor within the territory. These elements, which Raffestin (2008) presents, characterize a small-scale model used to explain transformations that occur during the process of territorialization. In this way, territorialization is the combination of "elements learned by actors in various systems which are at their disposition" (Raffestin, 2008, p. 30).

The concepts of territory and territorialization of Raffestin $(1993,2008)$, Haesbaert (2011), and Saquet (2008) are based on an understanding of the action of a subject within a space. They are based on the centrality of the subject, which is the focus of these authors' approach, seeking an understanding of not only its material aspect but also the immaterial and the symbolic aspect of territory as the locale of the actor's relationships, appropriations, creations, and inventions.

To understand how the actions of the participants in this study of the territorialization of space in settlements in Querência do Norte occur, in the following section, we will present the methodological strategies used to obtain and interpret the investigation data.

\section{METHODOLOGICAL PROCEDURES}

The development of this study seeks to understand the processes of territorialization in everyday life and work of settlers in agrarian reform in the municipality of Querência do Norte (PR). To do this, we have developed a 
descriptive study in order to interpret these territorialization processes based on the everyday life and on life stories of the interviewed subjects.

The data is of a qualitative nature and was collected using the oral history technique, which appears in three forms: oral life history, oral history themes, and oral tradition. For the development of this work, we have opted to use oral life history, which, to Ichikawa and Santos (2006), allows greater freedom for the interviewed subjects, who can relate their personal experiences because space is given to narrate their story in accordance with their experiences, which fits the proposed objective of this study.

To develop this study, we realized eight life interviews, which took place between July 2016 and July 2017, with residents of settlements and presettlements in the city of Querência do Norte. The interviewees are referred to by a pseudonym in order to maintain their anonymity. They are: Marta, who joined the MST at the age of 11 after her father lost his land due to bank debts; Lourdes, who entered the movement at the age of 17; Aparecida, who has lived 11 years in a pre-settlement; Célia, who entered the movement at 15 years of age and also lives in a pre-settlement; Ana, a cooperative veterinary technician who works directly with settlement farmers; João, 53 years of age, one of the leaders of the settlement; Marcos, 29 years of age and the son of João; and Mário, one of the historical leaders of the settlements in Querência do Norte.

After transcribing the interviews, we analyzed the life history narratives of the interviewees. In this context, we considered Barros and Lopes (2014, p. 55) in analyzing life histories, who believe that "the question that should guide the researchers is how to use these histories to advance the understanding of a reality". In this way, the narratives which make up these life histories should be observed by the researcher not just as personal histories but as a way of understanding an unknown social object, situation, or universe.

Therefore, according to Barros and Lopes (2014), the most relevant part of the analysis is the analytical research sample used, which can guide the researcher in terms of related issues, such as the person, work, militant choices, and engagements, which will be measured by the concepts and theories which sustain the study and dialogue with the narratives produced by the interviewees. In this way, we have related the narratives to theorization about territory and everyday life. Or, in other words, we have interpreted the data based on a constant dialogue with the authors who provided theoretical support for this investigation. 


\section{PRESENTATION AND INTERPRETATION OF THE DATA}

\subsection{Being part of the MST}

The processes of territorialization, which occur in a space, represent a point of departure for the subjects who construct relationships with the space and other subjects in everyday life (Raffestin, 1993, 2008). Thus, the interviewed settlers and pre-settlers come from different territorialities, but in many cases, they possess the same objectives which tie them to the space where they dwell today. These life histories show the relationship between these subjects and camp life:

During your youth, what was your dream? To have a piece of land. My father just had 18 acres, he couldn't get any more, so later the children had to work as employees, and he later joined them and went to the city, and I resisted. Of the six children, I'm the only one who is in the fight, you know? So, I feel fulfilled, you know? (João).

It was my brother who entered in the beginning. We didn't know it. So, my brother entered... and from that point on, we began to live with it, you know? I'd go there and visit him in the camp, see how his life was there. We were adolescents at the time, we didn't think much, you know? We took it in stride, but over time we learned and understood. From Tibagi [a municipality in the central region of Paraná], he came here to Querência, in the Pontal, where he stayed in the camp for the first time. Then my father came, and we decided to come here too. It was at this time that I left. I went back and got married. It's now been 11 years that I'm here. I haven't left again. I've been in this area for eight years. We've had good times when everything was calm in the camp, but we could leave, work and many people worked outside. It was relatively calm. Then we thought it better for each one to find their lot, you know? To try to get along in life. Because up until then, we worked on the land. But it wasn't the same, you know? We farmed, but just planting things for us to eat, you know? So, we were there in the camp until we came here to plant [...] I myself worked in a dairy cooperative. So, we had this daily commitment, you know? Then, we said let's stay on the lots and it will be better, won't it? And we came, and it really was better (Célia). 
In the previous excerpts, we can understand the beginning of the territorialization of Querência, hearing João, with his dream of having his own plot of land, and Célia, who got to know the movement over time. What calls our attention at this point is not just the rural history and trajectories, but the exploitation and use of work to, in fact, territorialize a new space.

Célia, in particular, mentions working on the land, but despite this, the sense of belonging, of having land in their name, was essential for things to get better. The territory of one's own piece of land functions in the imaginary and symbolic context. The future promise only takes shape through everyday practices, "that daily commitment". De Certeau, Giard, and Mayol (2013) mainly identify the practices of cooking and living as everyday practices that make it possible to understand the tasks and meanings which occur in the everyday lives of these subjects. Based on our interviews, we managed to identify, among the research participants, two types of practices that were capable of territorialization: working and studying. The excerpts below depict a few reports of the practice of studying:

So, our fight from the beginning was like this, it was from a perspective of having land, but having an education too. The fight to educate your children, you know? From this perspective, I think that Querência here, our idea is that all the parents want their children to study, something which they may not have succeeded in doing, getting their children an education. And we've succeeded [...] So, we left this situation of a precarious school for a better one, and the requests were for a, well, a school, a health post, telephone, electricity, you can see, we had nothing, you know? (João).

I had the great opportunity to study until the fourth grade [...] with the moving of the MST from one place to another... today we were in one space and tomorrow another, so I wasn't able to complete my education, you know? Then after we arrived here in Querência I resumed my education [...] there were various difficulties, you know? Then you think, for all these years that we've been sleeping in the damp, without a roof, trying to find food, a collective of people, you'd think that there would be some regret one day saying "our father had so many opportunities to live with an uncle or someone else, to work here or there". No. Never. Just thanking our father for having taken this position, for giving his family and raising his children with an objective, a goal (Marta).

In the excerpt referring to João, his demands go beyond just land in the physical sense but seek basic elements of survival and dignity, such as a better 
school, a health post, and other issues. We may also perceive in Marta's comments the constant process of moving from one space to another over a long cycle. Even so, in all these traveled spaces, its essence has remained the same. The difficulty in completing her education was just a cost of fighting. She expresses satisfaction with her father's decision to maintain a rural territory of customs and symbols, even though the physical space has changed.

In these interviews, there also emerges a mixture of studying and working, a type of learning among the settlement members. We can see this in the excerpt below:

Since we did not have the resources to look for education, to specialize, ourselves, we sought out in various settlements cultural practices with medicinal plants. [...] because there's someone from the riverbank who grew up in the islands and has something that he's always used [...] And there's another from a different group whose family came from Germany. So, we gather all of this together. [...] It's been like that with ointments, syrups, 12 herbs, and so many other things that we have learned here from others (Marta).

These practices related by Marta, of learning and producing for the consumption of the settlers and later selling to others, are typical of the ordinary man. De Certeau (2014) mentions in his writings the use of individual experience as a tactic and a way of improvising and utilizing the materials and resources at hand to create ruptures in everyday life. Learning and teaching these practices generate contact and the sharing of everyday life with others from other physical territories and also intertwines the territory of the settlers. These practices promote union and belonging to the same territory, whether camped or settled, the landless movement continues:

[...] we try to work but this organizational issue, working with women, with children, but we have a lot of difficulty, you know? [...] We wake up early to milk the cows [...], those of us here in Querência have gone through a period of a lot of persecution [...] I have trouble remembering the year, but we had a period that was very difficult, we have each other for protection so, a younger group organizes and performs activities, you see? Because, it's not that because one has difficulties that we're going to give up the fight, right? It's our work; this is our daily life. [...] Working there with medicinal plants. At the time, when we began our garden, we worked a bit more with medicinal plants. It was planting, harvesting, and drying. It's all a process, you know? (Lourdes). 
According to Lourdes, work also arises from difficulties, and it is through work that territorialization occurs. When some leaders were imprisoned, during greater persecution of the movement, other members had to act to make sure everyday activities continued with some degree of normalcy. It was by providing services, of feeling the difficulties of youth and a suffering life, that Lourdes transformed this territory and feels that she belongs to the movement.

Personal relationships, but more specifically love and passion, are another point that is associated with a given territory. We can observe this in the excerpts below:

She registered in that region of Santa Terezinha, close to Iguaçu Falls because her father lived there. And then she waited. I was camping, and we began to talk, and she said, "I've already registered; I'm just not camping like you are". So... we met there. Later in '90, we married. In '93, our first daughter was born (João).

My father said: "Look, I'm leaving. Your mother and I." Then we said: "No, I said we're going to stay." He [my brother] and I decided to stay. "No, we're going to stay here." And he said: "No, I just wanted to hear your opinion because you're older, you couldn't come, but your mother and I will be all right." So, we stayed and later I met my companion there, you know? We dated and ended up getting married (Lourdes).

[...] he [her husband] came from Água da Prata. He just has a sister here in this region, you know? His sister got a lot in Água da Prata. And since he was left out, they came here, those who were left out in Água da Prata came to Água do Ouro. I came with my father, camped here, and this is where we met. Love that was born in the camp. Everything began here (Aparecida).

We can see from these excerpts how the relationships between these subjects are fundamentally a practice of territorialization. The birth of a daughter, dating, and marrying, sharing a symbolic life, a physical life, and to still be in this fight is what makes each practice territorialize wherever they go. It makes the land where they signed the papers, or an improvised camp, their places of belonging, where they are transformed, act, and, mainly, fight. 


\subsection{Actions that territorialize}

Through ruptures in the everyday lives of the members, they get their sense of belonging. It is in their difficulties, their ruptures that, today, tomorrow, and afterward make the fight not just a dream and their main goal, but also one of their territorializing actions.

[...] so many things happened; it was very difficult there. The lack of water, the lack of prospects. People didn't adapt to the region. So, it was all a fight for us to demand to come to Querência do Norte, you know? (João).

The action of demanding shows perhaps one of the first practices of territorialization. In the case narrated by João, he explains how land which was provided by the government had many hills and was not very productive or appropriate for agriculture. Through their demands, the members managed to get a new piece of land, once again as the fruit of a conflict between those who rule the game - Incra and the government - and ordinary men - members of the MST.

The Fight (hereon written with a capital F) is almost immediately associated with demands: demonstrations, miles walked, and the power of the group's union gave these everyday practices a sense of belonging. They didn't just request new land but changes in the prerogatives established by the government. We can observe this below when João talks about the rule that only those who are married receive land:

[...] before, Incra was prejudiced, I believe, because they awarded people lots based on their points. Who had more points? The families with more children. They had a lot of points. Those who were single didn't get a lot, [...] then we waged a historic fight, imagine ' 86 , ' 87 , ' 88 , and we arrived here. When I arrived in ' $95, \ldots$ it worked out for me because I was married, but I had various friends who remain single to this day. [...] And then we said no! Being married can't be a rule for settling or not because it's a life option. I say this because a person spends ten years fighting to have space because he wants to be a farmer. Now he can't just because he is or isn't married? This led to a controversy, and in the beginning, they didn't agree. So, we said: “No! We're not going to give in on this. [...]. We were breaking a rule that in many areas, they simply exclude single people. This is why many made 
some arrangement, some half-improvised marriage [...] that wasn't the way to go, of course, in the Fight it's no good taking shortcuts, [...] and then we succeeded, didn't we? Today it's normal for Incra to settle single people as well (João).

The excerpt narrated by João shows two important things in terms of the theoretical question that we have established. The first is the question of territorialization practices of not just making demands and being successful in this, but, moreover, confronting the resistance of Incra, to beat it at its own game, changing the rules by facing a controversy and even using the verb "to conquer". In addition, we see another movement opposed to the use of strategy (De Certeau, 2014): the tactic of arranging an improvised marriage to indirectly "get around" the rules established for conquering the objective of the Fight. It is interesting that the interviewee himself, in going against this action, perceives that one shouldn't take shortcuts in waging the Fight. This reflection may be a consequence of another reported problem. In the excerpt below, we see another MST demand referring to the title of the lot:

The lot arrived with both names on it, but you know what happens a lot? When there's a fight, in the view of some of these farmers, the owner is the one whose name appears first on the contract [...]. It's complicated to explain, but let's suppose that a couple separates. Incra doesn't have a department that takes care of dividing lots. The lot belongs to the family. It doesn't divide lots, and it doesn't have a legal department that deals with this [...] You've separated? There is no specific legislation that covers this. And there have been many cases of disease, of alcoholism. And the wife ends up leaving with the children, and the man says: "No. The lot is mine. You want to leave? Go", and she leaves. Then...it changed. I was directly involved in a case like this. "No, send a contract in her name so that the husband understands that she's the owner as well" [...] Then contracts began to have the name of the wife. Now it's more of a question of cultural understanding. Now he understands that with her name appearing first, it's as if she's the owner (Ana).

As related by Ana, we have observed a conflict between the members of the MST, in which both share the same territory. The practice of splitting and the abandonment of Incra has led to the need for a demand by the group. In addition to being another practice to protect the movement, this also creates the need for "cultural understanding", in the words of the inter- 
viewee, or, in other words, the institution of rules for the belonging and good relations of all.

\subsection{Understanding what the fight is and where it can lead}

Perhaps the main point that motivates many of the territorial practices engaged in by members of the MST is the use of the term "Fight". This conventional word used with insistence reflects what we believe to be the cornerstone of the group, that which motivates them to wait for months and/ or years for their own piece of land. Up to a certain point, this is correct. However, as the interviews progressed, we perceived that "the Fight" is not a well-defined moral code, but rather the actions and practices which are responsible for territorialization functioning in a collective sense and, later, being transformed into something individual.

No. It's just as I said in the beginning. This task was given to me 13 years ago, let's say ten years ago. And I treat it as a task. Today, we can say that through the logic of space, I am the President of CEPAG (Ernesto Guevara Research and Training Center), but this doesn't change or anything. I'm still the same militant that I was before. The same [...]. (Marta).

The previous excerpt demonstrates not just the need for the union of all these subjects with a common objective but also the force with which it establishes roots. Marta demonstrates that, even though her tasks have changed, she is still the same militant that she was before, that is, part of the territory of which the Fight is the cornerstone. Her practices transform the territory into a conquest of the Fight. The militance of the MST guides their common desires, and each everyday practice allows these individuals to assume this militance as its members, which is also revealed in their language. In the eyes of an outsider, how is it possible to differentiate a small family farmer from a member of the MST who already has a piece of land? What distinctions separate one from the other? The answer appears in two more perceptible forms: vocabulary and history.

We will begin with vocabulary:

No. It's normal for everyone... to call everyone comrade... there are some who haven't married, but most have, just like religious believers. For them, it is "brother" or "sister", here it is comrade. "How are you, comrade?" that's what I say (Marcos). 
We perceived how rare it was for one of the interviewees to call us "comrade". They always referred to us as "you". In one of the interviews, we asked whether "comrade" was used to refer to members of the MST who are married. A synonym for husband/wife. The answer was that members of the movement call each other "comrade", which is thus an everyday act that symbolizes not just belonging to the Fight (based on who's speaking), but also that identifies who members are (who's referred to).

Even though the language is treated in a subtle form, and speech is considered an everyday practice by De Certeau (2014), there is a "historical" element that also is evident. The existence of a process of territorialization to Raffestin (1993) considers the society-space-time triad, or as Saquet (2008) adds, a historical aspect. The members of the MST spend a long time together, sharing their practices and experiencing their own divisions. Thus, as De Certeau (2014) mentions, everyday life in and of itself is not based on routine and tedium, but rather on conflicts or divisions caused by subjects who share everyday life.

A "comrade" recognizes the other because both share the camp's land. They share land in the present, which is the promise of land in the future. At this point, we perceived that everyday practices are also territorialization actions. An outsider cannot identify who is a member of the MST, but a member of the MST can identify who is outside their territory, outside the Fight.

We perceive this because of the history of violence suffered by the group. As demonstrated by the reports below, the members of the MST are constantly seen as powerless subjects, low in the social hierarchy, who often take on the role of thieves or lazy people, because they receive land to farm "for free": "But most of us are ordinary because we don't appear in the media" (Marta).

[...] we often stayed up all night. When they told us on a Monday that there would be a general meeting, what did we think? There goes Tuesday. That's what we thought. [...] Even the children felt down because the girls couldn't see whether a police car was passing by, and they couldn't say, "Look, Mom, the police are going to our tent, to destroy our tent and kick us out" (Aparecida).

We came by bus with the women and children, and the men rode on the top of a truck. All the way from Ponta Grossa here... so we arrived here and they [wanted] to scare us saying "Querência is very complicated, the police are at the entrance... there are gunmen... 1,500 of them" (João). 
Then the worst fight began [...] Then the directorship thought, "Let's do this". Yes, let's do this. We occupied there, we did it. That was where the dispute for power began. We wanted land, and the government said it had land but wouldn't show us where. It didn't say, "so, we can settle families in this place". They didn't say where they had space. But we were the ones who had to go get it. And we didn't have the power to know which were the areas. So, the government said that they had land but wouldn't show us where. [...] So, the UDR (Rural Democratic Union) pressured the government not to show the areas where the agrarian reform and the settlements would be [...]. So, our movement occupied the area, and then it began to be difficult, [...] they began to evict people around us and remove them, there were fights, and the police would come again. Other times the police wouldn't appear and just security people would appear whom we called gunmen. And they'd go there and evict us (Mário).

[...] there was more suffering. Today we say that there's suffering, but it isn't as bad. It used to be much worse. Then there was the issue of all that work, that everything paid less. There were people who worked all day to support their families, and there were people who couldn't manage because they were denied work due to their being landless (Aparecida).

We can observe the everyday practices creating ruptures and permitting the territorialization of space. The interviewees recognize their position of not determining the rules of the game (De Certeau, 2014), as Marta says, and that the members are ordinary people without power or ownership. Aparecida and Mário relate how sensitive the land situation is. At any moment, these interviewees themselves can be evicted, taken from their homes, and taken to an unknown territory. Violence, whether symbolic (being denied work due to being landless) or physical (being evicted from their homes), is an everyday condition of their lives.

This history of common fighting has made them strongly territorialize the space claimed in Querência do Norte. The relationships between the social actors, space, and time have constructed this territoriality. Being a life composed of relationships, territorialization has occurred through the collective nature of these relationships in which the subjects have been involved with space (abstract and/or concrete) and time (Raffestin, 1993). 


\section{FINAL CONSIDERATIONS}

The Fight and the sharing of the symbols and customs that bind the members of the MST to rural life are still subjects that are rarely addressed in studies of Administration. This silence exposes the issue of access to land in Brazil as a subject that has still not been settled and, as pointed out by Fernandes (2017), it preceded the fight for agrarian reform. Within this scenario, the MST is still seen as an anti-State and anti-democratic movement, being presented in a negative manner by intellectuals and most of the Brazilian press (Carter, 2009; Straubhaar, 2015). With this, violence in the field has come to be presented as coming from members of the MST, disqualifying their position as victims of the excesses committed by large landowners.

The objective of this study is to understand the processes of territorialization in the everyday lives and work of agrarian reform settlers in Querência do Norte (PR). Through collected life history narratives, we have observed some of the aspects present in the everyday lives of these workers who participate in these processes of territorialization, such as: the Fight that they share, their sense of belonging to country life, and the relationships between the subjects.

Based on the analyzed narratives, we understand that the Fight of those interviewed is related to everyday practices and, as a result, their processes of territorialization. The members of the MST are ordinary people to De Certeau (2014), and act step by step, practice by practice. In this sense, they experience their Fights every day, transforming their territory and making their current life conditions different from those of the past. This discussion is rarely presented in Administration, which silences the voices of ordinary subjects and rural workers who fight every day for the right to live and work in the field while they suffer a wide variety of forms of violence.

The subjects interviewed demonstrate a strong sentiment of belonging to their movement, with the word Fight being the most notable in their interviews. The Fight is what unites them. The fact that they are part of a larger movement seems to be what maintains the group's identity and makes it more cohesive. Politically, it is an active movement, and practices such as work, study, and demands promote a greater sense of belonging among the people who live the same historical reality of the Fight. We may observe from the results of this study that territorialization is accomplished through everyday practices and also the centrality of man in the construction of territorialization. As Raffestin $(1993,2008)$ shows, work and the disposition 
of these individuals and their material and symbolic mediators are important in this process of transforming space into territory. Time, the other element of territorialization, represents variations that occur in society along a longitudinal scale.

In this manner, the history shared by the members of the MST interviewed for this investigation has proved to be an important factor in their cohesion, sense of belonging, shared everyday practices, and, as a result, a process of territorialization and territoriality. It remains to be discovered which practices, places, and historical facts will make sense (or will not make sense) in the processes of territorialization for future generations of settler families. This study has already provided insights into this issue, but this is a subject that will be pertinent to the next article.

\section{PRÁTICAS COTIDIANAS E PROCESSOS DE TERRITORIALIZAÇÃO DE ASSENTADOS EM QUERÊNCIA DO NORTE, PARANÁ}

\section{RESUMO}

Objetivo: Compreender os processos de territorialização no cotidiano de vida e trabalho de assentados em Querência do Norte, Paraná.

Originalidade/valor: Este trabalho contribui com o contexto das discussões acerca do território e processo de territorialização (Haesbaert, 2011; Raffestin, 1993, 2008; Saquet, 2008) no cotidiano (De Certeau, 2014) de trabalhadores marginalizados pela sociedade de forma geral.

Design/metodologia/abordagem: Este artigo, de natureza qualitativa, foi desenvolvido a partir de dados coletados por meio de oito entrevistas de história de vida, com assentados, pré-assentados e moradores de Querência do Norte. Depois de transcritas, as entrevistas passaram por uma análise de narrativas.

Resultados: Identificamos que, a partir das práticas de trabalho, estudo e reivindicações, os assentados territorializam o espaço e ali passaram a criar suas próprias regras e normas de convivência. Em suas lutas pela terra, torna-se claro que seu local de pertencimento é o campo, justificando a insistência na luta pelo direito à terra para cultivar. O sentimento de pertencimento dos trabalhadores é representado pela luta que os 
une e os coloca como parte de um movimento maior. Tendo o homem como centro, a construção da territorialidade se faz no cotidiano de luta e trabalho dos assentados e pré-assentados em Querência do Norte.

\section{J palavras-chave}

Cotidiano. Território. Processo de territorialização. Assentados. Querência do Norte (PR).

\section{REFERENCES}

Alcadipani, R., Khan, F. R., Gantman, E., \& Nkomo, S. (2012). Southern voices in management and organization knowledge. Organization, 19(2), 131-143.

Barros, A., \& Carrieri, A. P. (2015). O cotidiano e a história: Construindo novos olhares na administração. Revista de Administração de Empresas, 55(2), 151-161.

Barros, V. A., \& Lopes, F. T. (2014). Considerações sobre a pesquisa em história de vida. In E. M. Souza (Org). Metodologias e analíticas qualitativas em pesquisa organizacional: uma abordagem teórico-conceitual. Vitória, ES: EDUFES.

Best, K., \& Hindmarsh, J. (2018). Embodied spatial practices and everyday organization: The work of tour guides and their audiences. Human Relations, $72(2), 1-24$.

Carrieri, A. P., Saraiva, L. A. S., \& Pimentel, T. D. (2008). A institucionalização da Feira Hippie de Belo Horizonte. Organizações \& Sociedade, 15(44), 63-79.

Carrieri, A. P., Perdigão, D. A., \& Aguiar, A. R. C. (2014). A gestão ordinária dos pequenos negócios: Outro olhar sobre a gestão em estudos organizacionais. Revista de Administração, 49(4), 698-713.

Carter, M. (2009). The landless rural workers movement and democracy in Brazil. Latin American Research Review, 45(4), 186-217.

Courpasson, D. (2017). The politics of Everyday. Organization Studies, 38(6), 843-859. 
De Certeau, M. (2014). A invenção do cotidiano: Artes de fazer. (22a ed.). Petrópolis: Vozes.

De Certeau, M., Giard, L., \& Mayol, P. (2013). A invenção do cotidiano: Morar e cozinhar. (12a ed.). Petrópolis: Vozes.

Domingues, F. F., Fantinel, L. D., \& Figueiredo, M. D. (2019). Between the conceived and the lived, the practiced: The crossing of spaces at the arts and crafts fair of Namorados Square in Vitória/ES, Brazil. Organizações \& Sociedade, 26(88), 28-49.

Duarte, B. J., \& Brewer, C. A. (2019). "Caught in the nets of 'discipline'": Understanding the possibilities for writing teachers' resistance to standardization in local policy. Educational Policy, 33(1), 88-110.

Fernandes, M. J. C. (2017). Da luta pela terra à luta pela Reforma Agrária no Brasil. Revista GeoInterações, 1 (1), 55-67.

Folmer, I., \& Meurer, A. C. (2019). Território em movimento. Revista NERA, $22(48), 8-13$.

Frers, L., \& Meier, L. (2017). Resistance in public spaces: questions of distinction, duration, and expansion. Space and Culture, 20(2), 127-140.

Fuini, L. L. (2019). A construção do território e as territorialidades: As dimensões do poder e seus sujeitos sociais em São João da Boa Vista/SP. Sinergia, 20(3), 184-195.

Gangneux, J., \& Docherty, S. (2018). At close quarters: Combatting Facebook design, features and temporalities in social research. Big Data $\mathcal{E}$ Society, 5(2), 1-10.

Godoy, A. G., \& Silva, P. B. (2008). Reforma agrária: Uma história de desenvolvimento de Querência do Norte - Paraná. RACE Unoesc, 7(2), 131-148.

Gonçalves, S. (2004). O MST em Querência do Norte-PR: Da luta pela terra à luta na terra (Dissertação de mestrado). Universidade Estadual de Maringá, Maringá, Paraná, Brasil.

Haesbaert, R. (2011). O mito da desterritorialização: do "fim dos territórios" à multiterritorialidade. Rio de Janeiro: Bertrand Brasil.

Hollender, R. (2016). Capitalizing on public discourse in Bolivia - Evo Morales and Twenty-First Century capitalism. Consilience: The Journal of Sustainable Development, 15, 50-76.

Ibarra-Colado, E. (2006). Organization studies and epistemic coloniality in Latin America: Thinking otherness from the margins. Organization, 13(4), 463-488. 
Ichikawa, E. Y., \& Santos, L. W. (2006). Contribuições da história oral à pesquisa organizacional. In A. Silva, C. K. Godoi, \& R. B. Mello (Orgs.). Pesquisa qualitativa em estudos organizacionais: Paradigmas, estratégias e métodos (pp. 185-209). São Paulo: Saraiva.

Instituto Nacional de Colonização e Reforma Agrária. (2017). Incra nos Estados - Informações gerais sobre os assentamentos da Reforma Agrária. Brasil.

Koch, K. (2017). The role of territoriality in the European Union multi-level governmental cooperation framework of Finnish-Russian cross-border cooperation. European Urban and Regional Studies, 26(2), 115-133.

Kuus, M. (2018). The terroir of bureaucratic practice: Everyday life and scholarly method in the study of policy. Environment and Planning C: Politics and Space, 37(4), 617-633.

Machado da Silva, L. A., \& Leite, M. (2008). Violência, crime e polícia: O que os favelados dizem quando falam desses temas? In L. A. Machado da Silva. Vida sob cerco: Violência e rotinas nas favelas do Rio de Janeiro (pp. 47-76). Rio de Janeiro: Nova Fronteira.

Meszaros, G. (2000). No ordinary revolution: Brazil's landless workers' movement. Race \& Class, 42(2), 1-18.

Munro, R. (2017). Creativity, organisation and entrepreneurship: Power and play in the ecological press of Money. Organization Studies, 39(2), 1-19.

Nielsen, K. D., \& Langstrup, H. (2018). Tactics of material participation: How patients shape their engagement through e-health. Social Studies of Science, 48(2), 259-282.

Oliveira, J. S. \& Cavedon, N. R. (2013). Micropolíticas das práticas cotidianas: Etnografando uma organização circense. Revista de Administração de Empresas, 53(2), 156-168.

Ortmann, G., \& Sydow, J. (2017). Dancing in chains: Creative practices in/ of organizations. Organization Studies, 39(7), 1-23.

Picheth, S. F. \& Chagas, P. B. (2018). Interfaces entre territorialidade e identidade: Analisando as vivências das mães do Grupo Maternati. Cadernos EBAPE.BR, 16(4), 788-801.

Raffestin, C. (1993). Por uma geografia do poder. São Paulo: Ática.

Raffestin, C. (2008). A produção das estruturas territoriais e sua representação. In M. A. Saquet, \& E. S. Sposito (Orgs.). Territórios e Territorialidades: teorias, processos e conflitos. São Paulo: Editora Expressão Popular.

Redshaw, T. (2017). Bitcoin beyond ambivalence: Popular rationalization and Feenberg's technical politics. Thesis Eleven, 138(1), 46-64. 
Reis, R. R. (2012). O direito à terra como um direito humano: A luta pela reforma agrária e o movimento de direitos humanos no Brasil. Lua Nova, 86, 89-122.

Ribeiro, R. C. L., Ipiranga, A. S. R., Oliveira, F. F. T., \& Dias, A. D. (2019). Uma "estética de lances" de uma "heroína ordinária": O reorganizar de práticas de resistências de uma Artesã. Cadernos EBAPE.BR, 17(3), 590-606.

Rodrigues, F. S. (2019). Sobre a transposição de métodos de outras áreas do conhecimento à pesquisa qualitativa em administração: Um estudo sobre a análise de discurso de Michel de Pêcheux, suas possibilidades, resistências e limitações. Revista Eletrônica Gestão e Serviços, 10(2), 2767-2789.

Santos, R. A. (2019). Na cidade em disputa, produção de cotidiano, território e conflito por ocupações de moradia. Cadernos Metrópole, 21 (46), 783-805.

Saquet, M. A. (2008). Por uma abordagem territorial. In M. A. Saquet, \& E. S. Sposito (Orgs.). Territórios e Territorialidades: Teorias, processos e conflitos. São Paulo: Editora Expressão Popular.

Saraiva, L. A. S., Carrieri, A. P., \& Soares, A. S. (2014). Territorialidade e identidade nas organizações: O caso do mercado central de Belo Horizonte. Revista de Administração Mackenzie, 15(2), 97-126.

Sewell, G., \& Taskin, L. (2015). Out of sight, out of mind in a new world of work? Autonomy, control, and spatiotemporal scaling in telework. Organizational Studies, 36(11), 1507-1529.

Straubhaar, R. (2015). Public representations of the collective memory of Brazil's Movimento dos Trabalhadores Rurais Sem Terra. Latin American Perspectives, 42 (3), 107-119.

Teixeira, J. C., Saraiva, L. A. S., \& Carrieri, A. P. (2015). Os lugares das empregadas domésticas. Organizações E Sociedade, 22 (72), 161-178.

Telles, V. (2010). A cidade nas fronteiras do legal e do ilegal. Belo Horizonte: Argumentum.

Wanderley, M. N. B. (2019). Reflexões sobre agricultura familiar e campesinato no Brasil e na França. In O. T. De Souza, M. De Andrade, A. C. Fleury, J. P. Billaud, \& M. Zanoni (Orgs). Diálogos contemporâneos acerca da questão agrária e agricultura familiar no Brasil e na França. Porto Alegre: EDIPUCRS.

Wanderley, M. N. B. (2014). O campesinato brasileiro: Uma história de resistência. Revista de Economia e Sociologia Rural, 52 (1), S025-S044. 


\section{AUTHOR NOTES}

Eline G. O. Zioli, master from the Graduate Program in Business Administration, State University of Maringá (UEM); Fábio S. Rodrigues, PhD from the Graduate Program in Business Administration, UEM; Evandro L. Gaffuri, master from the Graduate Program in Business Administration, UEM; Elisa Y. Ichikawa, PhD from the Graduate Program in Production Engineering, Federal University of Santa Catarina (UFSC).

Eline G. O. Zioli is now teacher EBTT at the Department of Management of Federal Institute of Education, Science and Technology of São Paulo (IFSP); Fábio S. Rodrigues is now adjunct professor at the Department of Business Administration of Federal University of Mato Grosso do Sul (UFMS); Evandro L. Gaffuri is now alumnus at the Graduate Program in Business Administration of UEM; Elisa Y. Ichikawa is now associate professor at the Center for Applied Social Sciences of UEM.

Correspondence concerning this article should be addressed to Eline G. O. Zioli, Avenida Zélia de Lima Rosa, 100, Portal dos Pássaros, Boituva, São Paulo, Brazil, CEP 18.550-000.

E-mail: elinezioli@ifsp.edu.br

\section{EDITORIAL BOARD}

\section{Editor-in-chief}

Gilberto Perez

Associated editor

Renata Silva de Carvalho Chinelato

Technical support

Vitória Batista Santos Silva

\section{EDITORIAL PRODUCTION}

Publishing coordination

Jéssica Dametta

Language editor

Daniel de Almeida Leão

Layout designer

Emap

Graphic designer

Libro 